$\begin{array}{llr}\text { Бенчук В.О., } & \text { аспірант } & \text { Національного } \\ \text { університету } & \text { “Острозька академія” } \\ \text { (м. Острог); } & & \end{array}$

Грицюк В.М., кандидат історичних наук, доцент, провідний науковий співробітник науково-дослідної лабораторії науководослідного иентру воєнної історії НУО України імені Івана Черняховського (м. Київ)

\title{
ПЕРШІ БОЇ ЗА ІЛОВАЙСЬК У СЕРПНІ 2014 РОКУ
}

Увазі наукової громадськості пропонуються результати воснноісторичного дослідження, присвяченого периим боям за Іловайськ між захисниками України та російськими окупаційними військами у серпні 2014 року. Внаслідок відсутності архівних документів та недостатнього опрацюювання порушеної теми в історіографії автори трунтують своє дослідження на спогадах учасників подій, використовуючи сучасні методологічні підходи усної історії.

Ключові слова: агресія Російської Федерацій, збройний конфлікт на Сході Украӥни, антитерористична операція, Іловайськ.

Збройна боротьба за Іловайськ - це особлива та складна сторінка у протистоянні збройній агресії Російської Федерації. Вона привертає до себе увагу державних посадовців, політиків, юристів, науковців, військових експертів, журналістів, громадськості загалом. Такий інтерес та зацікавленість до подій навколо Іловайська свідчить про їх актуальність.

Висвітленню перебігу боротьби за цей важливий вузол комунікацій приділили увагу безпосередні учасники подій - Р. Зіненко та І. Родін. Р. Зіненку належать кілька праць: “Іловайський щоденник”, а також двотомник “Війни якої не було. Хроніка Іловайської трагедіи” [5; 27]. У 
першій роботі він описує події крізь власне бачення та переживання. У двохтомному виданні зібрано спогади інших учасників, що систематизовані у хронологічно-проблемній послідовності, та розкрито хронологію подій.

Українські дослідники, зокрема Ю. Бутусов, Я. Тинченко, А. Павлюк, М. Жирохов, С. Марко, розглядали переважно завершальний етап Іловайської операції $[4 ; 7 ; 24 ; 29 ; 30]$. Також до цієї теми у своїх роботах зверталися Г. Перепелиця, П. Гай-Нижник, С. Стеценко та інші цивільні історики [25]. Однак їх роботам притаманний описовий характер, дослідженням бракує оцінок із позицій теоретичних засад воєнного мистецтва. Іловайські події досліджують також науковці - представники країни-агресора. Так, російський історик А. Циганок розкрив “русский взгляд" на події в Іловайську [33]. М. Литвинов розглянув Іловайську операцію через призму характеристики тактичних можливостей незаконних збройних формувань так званої ДНР. При цьому російські автори фальсифікують історичні факти [26].

Метою статті є воєнно-історичний опис перших боїв за Іловайськ, що на сьогодні залишаються недостатньо висвітленими у літературі. Автори намагаються заповнити цю прогалину.

4 серпня 2014 р. у штабі сектору “Б” (населений пункт Старобешеве), було проведено нараду, на якій були присутні О. Мотрій (командир батальйону територіальної оборони (далі - бТрО) “Кривбас"), Ю. Лисенко (командир роти 39-го бТрО “Дніпро-2”), представники 93-ї окремої механізованої бригади (далі - омбр) і 51-ї омбр. Начальник оперативного відділення сектору довів завдання: “Кривбас" мав оточити та звільнити Іловайськ від противника [13]. Про це завдання згадує і начальник озброєння сектору Ю. Мельник. 51 омбр після надання підтримки у звільненні міста мала продовжити рух на Зугрес і перекрити трасу Шахтарськ - Донецьк, щоб ворог не міг отримувати поповнення боєприпасами та найманцями [31, арк. 49]. 
Спочатку звільнення Іловайська не розглядалося як окрема операція. Це була одна зі складових дій сил АТО. Дещо пізніше, 14-24 серпня 2014 року проводилася відповідна операція сектору “Б”. Згодом, коли українські війська були оточенні ЗС РФ, проводилася операція під назвою "Виведення підрозділів ЗС України, НГ України та добровольчих батальйонів з оточення під Іловайськом" [7, с. 115].

Відомо, що 5 серпня було ухвалено бойове розпорядження сектору “Б”, згідно 3 яким “вранці 7 серпня силами 40-го бТрО у взаємодії 3 3-ю батальйонно-тактичною групою (далі - БТГр) 51-ї омбр провести рейдові дії у напрямку Старобешевого, Новокатеринівки, Іловайська і до кінця доби провести прочісування i звільнення міста Іловайськ від терористів. Установити повний контроль над містом і у взаємодії із підрозділами 3-ї БТГр 51-ї омбр зайняти сім взводних опорних пунктів північніше та східніше Іловайська" [2, с. 379].

Цього ж дня у Дніпропетровській обласній державній адміністрації відбулася зустріч генерал-лейтенанта Р. Хомчака, командувача сектору “Б” 3 командирами добровольчих батальйонів С. Семенченком (“Донбас”), Ю. Березою (“Дніпро-1”), А. Білецьким (“Азов”) та начальником його штабу В. Трояном, а також з А. Філоненком (“Шахтарськ”). Під час зустрічі було обговорено можливість координації дій добровольчих підрозділів із ЗС України під загальним командуванням Р. Хомчака у секторі “Б” [31, арк. 239].

Отримавши письмовий наказ, “Кривбас" приступив до виконання завдання. До нього були залучені сили батальйону (близько 100 бійців), група Добровольчого українського корпусу Правий Сектор (ДУК ПС, загін Сича) [22], а також дві групи спецпризначенців - 3-го окремого полку спеціального призначення (10 осіб) та 74-го окремого розвідувального батальйону (орб). Підтримували наступ два танки та одна БМП зі складу 51-ї омбр, а також бронетранспортер (БТР) 74-го орб [5, с. 23]. 
Зведена група мала на меті обійти місто зі сходу через с. СтепаноКринка, де розвідка знайшла укріплений район противника. Під час руху до зазначеного місця танки почали стріляти по посадках, де був помічений ворожий дозор [22]. Блокпост противника був облаштований на підступах до села за посадкою, ліворуч від української колони. Це давало противнику тактичну перевагу над українськими військами - можливість приховано діяти, на відміну від сил, що атакували і пересувалися відкритим полем [8]. Противник атакував колону i декількома пострілами 3 ручного протитанкового гранатомета (РПГ-7) пошкодив танк, який змушений був відступити. Інший танк, використавши бойовий комплект, також відступив [22].

Попри несприятливі умови українські бійці продовжували вести бій наявними силами. Їх почали обстрілювати снайпери противника, що змусило їх залягти або заховатися за бронетехнікою, яка залишилася у бою. Ворог, маневруючи, обійшов 3 флангу і відкрив вогонь не тільки 3 фронту, а й 3 тилу. Було втрачено офіцера “Кривбасу” майора В. Кордабньова. Зведена група була змушена відступити [8].

Після повернення колони О. Мотрію повторно наказали здійснити захід в Іловайськ цього ж дня. Наступальні дії запланували по прямій дорозі Кутейникове - Іловайськ. Командир зібрав увесь особовий склад батальйону, вільний від виконання службових обов'язків, та віддав наказ готуватися до виконання завдання [13]. Загальний план дій, донесений особовому складу, виглядав так: коли колона зустрічає укріплений район противника, бойова розвідувально-дозорна машина (БРДМ), що рухається попереду, відкриває по ньому вогонь, а інші автомобілі з бійцями, які слідують за нею, по черзі підтягуються і відкривають вогонь із гранатометів [5, с. 34-35]. Цей маневр давав змогу іншим перегрупуватися та змінювати один одного для ведення безперервного вогню по противнику [8]. Унаслідок цього бою українські бійці зазнали втрат (загинули сержант С. Ганічев та солдат М. Кочура) та відступили [17]. 
8 серпня 2014 р. на базу дислокації батальйону “Донбас” у м. Курахове прибули міністр внутрішніх справ України А. Аваков, секретар Ради національної безпеки і оборони О. Турчинов і командувач сектору “Б” генерал-лейтенант Р. Хомчак. На зустрічі 3 командирами добровольчих батальйонів було обговорено участь їхніх підрозділів у звільненні Іловайська [19]. Вони отримали наказ допомогти підрозділам ЗС України знищити основні сили незаконних військових формувань в Іловайську і взяти його під контроль [15]. “Шахтарськ” отримав завдання розділитися - частину сил мали залучити в Іловайську, іншу - в районі Красногорівки [31, арк. 181]. Під час наради та отримання завдання по звільненню Іловайська присутні командири висловили побоювання, що для досягнення поставлених цілей недостатньо залучених сил. Проте вони розуміли важливість Іловайська для оточення Донецька і розраховували на прибуття резервів із початком наступу [1].

Цього ж дня, після зустрічі у м. Курахове Р. Хомчак віддав наказ особовому складу “Кривбасу” влаштувати опорні пункти для контролю шляхів, що ведуть в Іловайськ [5, с. 46-47]. Після реорганізації і поповнення своїх сил іншими бійцями, котрі повернулися з блокпостів, що знаходилися в районі м. Амвросіївка, “Кривбас" приступив до виконання поставленого завдання [13].

9 серпня розпочалася підготовка добровольчих батальйонів до звільнення міста силами декількох підрозділів (“Донбас", “Шахтарськ”, “Азов”), а також групи “Купол”, яка складалася з ветеранів морської піхоти і входила до складу “Донбас". “Шахтарськ”, “Донбас” і “Купол” прибули на місце збору в с. Осикове, звідки на світанку вирушили на вихідну позицію до с. Многопілля [11]. “Азов” розташувався у м. Старобешеве, поблизу базового табору підрозділу “Кривбас” [14].

Наступного ранку на опорному пункті 39-го батальйону ЗС України “Дніпро-2” у с. Многопілля зібралися усі підрозділи, задіяні у наступі. Було проведено нараду, на якій узгодили спільний план дій: по прямій дорозі 
Кутейникове - Іловайськ наступає “Донбас", справа від них - “Азов” та “Шахтарськ”. У зв'язку з тим, що особовий склад “Шахтарська” не був забезпечений бронежилетами і касками, він мав йти за бійцями “Азову” та відволікати противника вогнем [15]. Завдання батальйону “Азов” було, за словами командира їхньої групи М. Березового (“Береза”, загинув у цьому бою), який був на нараді у штабі, рухатися за БМП [20].

Командир батальйону “Донбас" С. Семенченко довів особовому складу, що загальну координацію дій здійснює він, перебуваючи у резерві, а штурмовою групою керує Т. Констанчук (“Бішут”) [27, с. 20]. Їхнє бойове завдання - виявити слабкі та сильні сторони противника, який закріпився в місті, i, якщо оборона буде погано організованою, спробувати звільнити населений пункт [24, с. 16].

Неоднозначним питанням залишається розвідувальні дані, якими оперували при плануванні завдання. Як стверджують висновки Тимчасової Слідчої Комісії Верховної Ради України, командування використовувало наступні розвідувальні дані: відсутність організованої оборони та 30-80 сепаратистів 3-поміж місцевих мешканців, які мають стрілецьку зброю. Протилежними даними володіло керівництво батальйону "Кривбас" наявність в Іловайську укріпрайону та значної кількості добре озброєних терористів, яке командування не взяло до уваги [32, арк. 11].

Згідно із задумом було сформовано дві групи:

- дві роти “Донбасу” (близько 200 бійців), група "Купол” (36 бійців), загін Марлена Місіратова (“Татарин”) ДУК ПС, а також екіпаж бойової машини піхоти (БМП) 51-ї омбр і бронетранспортер (БТР-60) батальйону “Донбас” [16];

- $\quad 40$ бійців “Азову” під прикриттям БМП 51-ї омбр та саморобної броньованої машини “Пряник” [20], а також близько 130 вояків “Шахтарська" на легкових автомобілях [31, арк. 193].

Вони утворили одну суцільну колону. Очолювала ï група, що наступала по прямій дорозі Кутейникове - Іловайськ. Рухатися почали 
приблизно о 06:00 ранку. Коли вирушила колона на чолі із “Донбасом”, услід за нею почала рухатися друга група, яка на перехресті при виїзді із с. Многопілля звернула праворуч і попрямувала через залізничний переїзд [20].

Першою вступила у бій колона, яка наступала по головній дорозі та була атакована противником під час руху біля моста. Праворуч із лісосмуги противник відкрив вогонь у бік БМП з РПГ-7, а також зі станкового автоматичного гранатомета (АГС-17) та автоматів. Група відразу зупинилася, а особовий склад зайняв позиції для бою [9]. Внаслідок обстрілу 3 гранатомета i АГС-17 було пошкоджено БМП. Екіпаж зазнав незначних поранень, а навідник-стрілок Д. Сурі отруївся пороховими газами через швидкострільну стрільбу і погану вентиляцію всередині машини [10]. Для відбиття атаки вогонь у бік противника вели із усього озброєння - HCB-12,7 “Утьос", а також ЗУ-23-2, яку група бійців “Донбасу” викотила попереду пошкодженої БМП. Результатом таких дій стало відбиття атаки, ліквідація кількох бойовиків та відхід останніх у місто [5, с. 67-68].

Ще одна засідка була організована зверху, на мосту. У лісосмузі були розміщені позиції противника. Під час контактного вогню під віадуком командир групи “Купол” В. Дегтярьов (“Сансей”), піднявшись на нього, помітив вогневі позиції і закидав їх гранатами. Бійці “Донбасу”, котрі вели бій внизу, почувши звуки вибухів на мосту, відкрили вогонь по своїх. Але завдяки вчасній реакції Тенгіза Тетруашвілі (“Тринадцятий”) вогонь було припинено і ніхто не постраждав [10]. Це дало змогу штурмовій групі безперешкодно продовжити рух у напрямку міста під прикриттям БТР-60, який після евакуації БМП очолював колону. Однак із ним постійно виникали проблеми - відмовляв двигун, переставав працювати кулемет. Під час наступальних дій його ремонт здійснював заступник командира по озброєнню батальйону “Донбас” Ю. Літвінський (“Монгол”) [23].

Для прикриття тилу командир штурмової групи Т. Констанчук залишив частину вояків “Купола” та відділення О. Дейнеги (“Чуб”), які мали 
контролювати територію навколо віадука. Позаду основних сил на відстані 300 м рухався взвод снайперів під командуванням Д. Куліша (“Сімьорка”) [16]. Зліва у лісопосадці здійснювала розвідку група “Татарина” ДУК ПС, а праворуч біля залізничних колій згідно з задумом мали діяти підрозділи “Азов” і “Шахтарськ” [23].

3 моста В. Дегтярьов помітив на залізничних коліях групу бійців позаду основних сил. За жовтими наліпками на рукавах їх було ідентифіковано як українських вояків. Окрім них, попереду було помічено ще одну групу з 15-20 осіб, але без розпізнавальних знаків на рукавах. Про це доповіли командиру штурмової групи Т. Констанчуку, але він, як і решта, вважав, що це група бійців “Азову” і “Шахтарська” [10]. Однак відсутність радіозв'язку між підрозділами не давала їм змоги координувати свої дії. Зв'язок здійснювався лише через смс-повідомлення між командиром батальйону “Донбас" С. Семенченком і командиром загону “Азов” С. Коротких (“Боцман”) [20].

Оцінивши ситуацію і зрозумівши, що бійці без розпізнавальних знаків не “Азов” і “Шахтарськ”, В. Дегтярьов прийняв рішення разом із В. Савічуком (“Сава”), Ю. Гріньковим (“Очаків”) та В. Войлоковим (“Фура”) переслідувати їх [10]. Завдання про підтримку групи “Купол” від командира штурмової групи отримав О. Дейнега, який вирушив на допомогу зі своїми бійцями - С. Міщенком (“Яр”), В. Лавреновим (“Лавр”), В. Ліньовим (“Крук”), В. Антоновим (“Літак”) і В. Ковальчуком (“Тритон”). Вони перейшли посадку і вийшли на залізничне полотно, залучивши бійця зі взводу снайперів К. Андрійчука (“Том”) [12]. Згодом частина вояків “Купола”, котра мала контролювати територію біля моста, також вирушила ближче до штурмової групи.

Зведена група “Купола” і “Донбасу”, проминувши приміщення митниці, що вже було зачищене і зайняте бійцями зі взводу снайперів, продовжила рух у бік Іловайська [11]. На відстані декількох десятків метрів від митниці зник радіозв'язок. Щоб зв'язатися 3 основними силами, 
В. Дегтярьов виліз на цистерну. У цей момент противник відкрив вогонь. Першими пострілами було вбито В. Антонова і поранено командира групи “Купол”, якому куля потрапила в біцепс, а вибухом гранати відірвало кілька пальців на руці [10]. Решта бійців зайняли позиції під вагонами і вступили у бій, що полягав, переважно, у киданні гранат РГД-5, властивості яких не давали змоги нанести противнику значної шкоди.

Дізнавшись про втрати, Т. Констанчук віддав наказ відступити. В. Ковальчук кинув у бік противника декілька гранат, що дало можливість здійснити відхід, не евакуювавши тіло загиблого. Бійці повернулися до митниці, де з'єдналися з іншими вояками та поповнили боєкомплект. Під час цих дій місце засідки було відпрацьовано мінометним вогнем, після чого загін повернувся забрати тіло В. Антонова [12]. Однак тіло загиблого зникло, а криваві сліди вели до огорожі, за якою були позиції противника. Не знайшовши тіла і потрапивши під вогонь із засідки, група відступила [18].

Інша колона із батальйонів “Азов” і “Шахтарськ”, повернувши у бік залізничного переїзду, рухалася між двома полями грунтовою дорогою, що повертала ліворуч. На чолі колони їхала БМП 51-ї омбр. Її десантом були вояки “Азову”, які побачили на дорозі місцевого мешканця, котрий рухався їм назустріч на велосипеді. Вони запідозрили, що він може бути коригувальником артилерійського вогню, тому зупинилися для його перевірки. Місцевий мешканець був похилого віку і дуже погано чув, що ускладнило його перевірку. Під час допиту бійці побачили відблиски, які вони сприйняли за оптику снайперських гвинтівок, тому здійснили у їхній бік декілька пострілів з автоматів. Натомість противник відкрив вогонь [14].

Бійці “Азову” розгорнулись у бойовий порядок для наступу. Їх атаку підтримували БМП і власна саморобна броньована машина “Пряник”, на якій було встановлено великокаліберний кулемет НCВ-12,7 “Утьос". По фронту українських сил розташовувався добре укріплений блокпост противника 3 організованими стрілецькими позиціями навколо нього. По ньому вели вогонь з БМП і “Пряника" [20]. 
“Шахтарськ” перемістився ліворуч від дороги, до лісосмуги, де зайняв позиції для бою. Бійці підрозділу почали стріляти по розташуванню противника з усіх наявних вогневих засобів, що дало змогу бійцям “Азову” під прикриттям бронетехніки тактичними маневрами наблизитися до ворога [15].

Прямолінійний наступ по дорозі робив броньовану машину "Пряник" легкою мішенню для противника, тому вона з'їхала праворуч, у поле соняшників. Однак противник, розуміючи значення підтримки атаки броньованими засобами, намагався вивести “Пряник" з ладу, відкривши вогонь із важкого озброєння. Декількома влучними пострілами противник пошкодив зварну стійку, на якій було закріплено кулемет [20].

Слідом за “Пряником” у поле звернула БМП 51-ї омбр. Проте там іiі двигун вийшов 3 ладу і вона не могла стріляти [14]. Незважаючи на пошкодження "Пряника" та несправності єдиної БМП, що могли допомогти в подальшому наступі, підрозділи продовжували вести бій [30]. Завданням БМП стало прикриття бійців, які, сховавшись за нею, продовжували відстрілюватися. Декількома пострілами ворожого снайпера було вбито гранатометника “Азову” А. Дрьоміна (“Світляк”). При спробі забрати тіло загиблого М. Березовий зазнав поранення, що спричинило сильну кровотечу. Він власноруч перев'язав собі ногу i намагався витягнути тіло свого побратима. Для їх евакуації прибула машина, однак під час евакуаційних дій було поранено Р. Сокуренка (“Сокіл”), якому ворожий снайпер влучив у ділянку ребер, де на бронежилеті відсутні захисні пластини [14].

М. Березовому намагалися надати медичну допомогу, але оскільки поранення було в області пахової артерії, кровотечу якої неможливо зупинити перев’язуванням, він помер на місці. Медики батальйону “Азов”, які могли надати фахову медичну допомогу, розгубившись, поїхали 3 колоною “Донбас" [20]. Р. Сокуренку надали медичну допомогу, але куля, що ввійшла збоку, пошкодила практично всі внутрішні органи, спричинивши 
сильну внутрішню кровотечу [14]. Він помер 22 вересня в госпіталі Бундесверу (збройні сили Німеччини) м. Ульм [6].

Перші втрати та вдала робота ворожого снайпера викликала деяку паніку в лавах “Азову”. Ю. Сременко (офіцер бойового управління батальйону “Азов”) попросив у Р. Онищенка (заступника командира “Шахтарська”) кількох снайперів у своє підпорядкування, щоб знайти і знешкодити снайпера противника [5, с. 77]. Решта бійців “Шахтарська" згодом відійшла на вихідну позицію, оскільки у них закінчився боєкомплект [15].

Противник здійснив тактичний маневрений обхід та перейшов у контрнаступ, намагаючись оточити українських бійців. С. Коротких, оцінивши ситуацію, прийняв рішення про відступ. Після вивезення з поля бою пораненого Р. Сокуренка "Пряник” і БМП, яку екіпаж зміг відремонтувати й завести, а потім решта вояків на легкових автомобілях почали відходити [20].

Батальйон “Донбас” продовжив рух у напрямку міста. Він дістався передмістя, де дорога повертала ліворуч. Перед поворотом розташовувався укріплений район противника - позиції у чотирьохповерховій будівлі, а за нею - організовані блокпости. У цьому районі українські бійці зупинилися і розпочали контактний бій. Противник, розмістившись на флангах, утримував свої позиції.

Для підтримки атаки була задіяна 3У-23-2, що відпрацювала по лісопосадці, де могла бути засідка противника. Також для підтримки вогнем було застосовано БТР-60, однак ворожий вогонь пошкодив його колеса, i закінчилося пальне. 3 огляду на це було прийнято рішення евакуювати його 3 місця бою, відправивши автомобіль спеціального призначення “КрАЗ”. Крім того, закінчилися боєприпаси для автоматичної зброї, гранатометів і 3У-23-2, що була єдиним важким озброєнням після евакуації БТР-60 [23].

За боєприпасами було відправлено машину з бійцями групи “Купол” i батальйону “Донбас”. Їхнім завданням було привезти додатковий 
боєкомплект із с. Многопілля, а загін бійців “Купола” мав намір вирушити на пошуки своїх зниклих розвідників Ю. Грінькова та В. Войлокова. Іншим завданням було повторно оглянути позиції противника біля моста i позбирати трофейну зброю та боєприпаси [5, с. 91]. Щоб нанести вогневе ураження по противнику, Т. Констанчук запросив дозвіл на обстріл укріпленого району мінометним вогнем. Мінометники, розташовані в с. Полтавське, за допомогою коригувальних дій вояків ДУК ПС знищили склад боєприпасів противника. Українські бійці у момент роботи мінометів розташовувалися на узбіччі головної дороги для відпочинку, очікуючи надходження боєприпасів [9].

Автомобіль, що вирушив за ними, зупинився під віадуком, щоб висадити бійців "Купола". Під час огляду місця засідки та пошуку зниклих бійців “Купола" була отримана інформація, що вони вирвались із засідки і десь переховуються. Також під час огляду території навколо моста були помічені дві жили товстого дроту, що свідчили про намір противника підірвати міст, щоб закрити шлях відходу. Раптом противник відкрив вогонь [5, с. 93-94]. Внаслідок організованої засідки батальйон “Донбас” втратив трьох бійців Ю. Літвинського, Ю. Бойка (“Немо”) і Р. Мотичка (“Комуніст”). На підмогу решті українським воякам, які продовжували бій, виїхало декілька автомобілів. По прибуттю до моста виявилось, що противника вже не було, а бійці “Донбасу” ціною власного життя врятували решту від оточення [16]. Після відпрацювання мінометів особовий склад ДУК ПС провів розвідку і виявив, що у лісопосадці організована засідка 3 великою кількістю живої сили. Оцінивши ситуацію (противник вільно працює в тилу; невідомо, де батальйони “Азов” та “Шахтарськ”, з якими немає зв'язку; відсутня підтримка бронетехніки; закінчилися боєприпаси в усіх бійців), T. Констанчук, узгодивши своє рішення із командиром батальйону С. Семенченком, віддав наказ про відступ [9].

Противник, відбивши атаку українських бійців, почав атакувати українські сили, що намагалися оточити місто. Найбільша проблема виникла 
у с. Грабське, де 11 бійців батальйону “Кривбас" опинилися в повному оточенні, зазнаючи систематичних атак. У зв'язку з цим 11 серпня підрозділи “Азов” та “Кривбас” спробували деблокувати їх. Операція пройшла успішно, але були втрачені захоплені позиції, які 13 серпня було повернуто під контроль за підтримки 73-го морського центру спеціальних операцій [17].

Також 13 серпня після повернення решти бійців “Шахтарська" з району Красногорівки було прийнято рішення силами цього підрозділу провести розвідку боєм на місці їхнього наступу 10 серпня [21]. Ïї мета була “обстріляти” бійців “Шахтарська”, а також визначити вогневі позиції противника. Підтримували бійців дві одиниці МТ-12 “Рапіра" та дві БМП зі складу 51-ї омбр [5, с. 131-132]. Після розвідки боєм основні дороги в Іловайськ були задимлені, а бійці батальйону “Азов” по радіостанціях провели імітацію атаки для послаблення морального духу противника [21].

Подальші події свідчать про те, що одночасно 3 першими спробами звільнити Іловайськ російське військово-політичне керівництво вирішило вдатися до повномасштабного вторгнення військ РФ на територію України. Мета операції полягала в оточенні та розгромленні сил АТО. Було проведено зміни у керівництві квазідержавних утворень: з Донецька до Росії відкликали I. Стрєлкова та “прем’єр-міністра “ДНР” О. Бородая, а 3 Луганська В. Болотова, який керував “ЛНР”. “ДНР” очолив О. Захарченко, а “ЛНР” I. Плотницький [3, с. 42]. У середовищі російських окупаційних військ ця операція ЗС РФ на території України отримала назву “Північний вітер” [26].

Як стверджує дослідник М. Жирохов, уже 12 серпня на українську територію зайшли колони ЗС чисельністю до 1200 осіб 18-ї гвардійської мотострілецької бригади 58-го Південного військового округу [4]. Одна із цих колон атакувала позиції українських бійців біля кордону, про що 13 серпня о 04:00 доповів оперативний черговий сектору “Д” у штаб АТО. У повідомленні зазначалося, що мала місце танкова атака в районі зосередження БТГр і командного пункту 30-ї омбр силами приблизно 20 танків РФ і піхоти противника [31, арк. 7-8]. 
Перетин українського кордону колонами ЗС РФ також зафіксували західні журналісти - московський кореспондент видання “The Guardian” Шон Уокер, журналіст газети “Telegraph” Роланд Оліфант та Ендрю Рот 3 “Тhe New York Times". На своїх сторінках у соціальній мережі “Twitter” вони повідомили, що український кордон перетнула російська бронетехніка, в якій було декілька десятків БМП, БТР і вантажівок [28].

ЗС РФ у взаємодії з колабораціоністами, обстрілюючи українські позиції артилерійським вогнем, який коригували безпілотні літальні апарати, продовжували атаки за допомогою піхоти та бронетехніки. Внаслідок цього українська армія втрачала свої позиції та відступала від кордону в глиб української території, залишаючи відкритим фланг сектору “Б” [29, с. 8].

На тлі драматичного розвитку подій 15 серпня у штабі сектору “Б” відбулася нарада для розроблення нового плану звільнення міста, що перебачав такі дії:

- розмістити на стратегічно важливих позиціях навколо м. Іловайськ танки і бронетехніку для запобігання підходу підкріплення терористам з боку м. Зугрес або їх втечі з м. Іловайськ;

- $\quad$ залучити артилерію, яка димовими снарядами мала створити в центральній та найбільш укріпленій частині міста задимлення;

- бійцям батальйону “Шахтарськ” залягти на обраних позиціях та імітувати атаку району задимлення;

- штурмувати місто 3 різних сторін підрозділами, підсиленими танками та БТР [24, с. 18].

Цей план було затверджено в штабі АТО. 16 серпня у с. Урзуф на базі батальйону “Азов” командир сектору “Б” провів спільну нараду 3 заступником міністра внутрішніх справ С. Яровим [32, арк. 13] (на прохання Р. Хомчака штаб АТО призначив його куратором добровольчих батальйонів, який мав ними командувати через командувача сектору) [31, арк. 52] та командирами батальйонів С. Семенченком, Ю. Березою, А. Білецьким та А. Філоненком. На нараді командирам батальйонів було донесено загальний 
план наступу та дату штурму - 18 серпня [32, арк. 13]. Для звільнення міста знову були задіяні добровольчі батальйони, які підтримували кілька щойно сформованих тактичних груп ЗС України, у зв’язку 3 відсутністю в розпорядженні штабу АТО військ, укомплектованих контрактниками $[25$, c. 621$]$.

На момент планування повторного звільнення міста 18 серпня Іловайськ вдалося оточити блокпостами - 40-01 - с. Грабське, 40-02 с. Кобзарі, 40-03 - с. Зелене та 40-04 - с. Покровка. Позиції на блокпостах утримували в основному бійці батальйону “Кривбас”, яких підтримували важким озброєнням та бронетехнікою 51 омбр, 17 окрема танкова бригада та 93 омбр. Це давало змогу контролювати основні підходи до міста та успішно виконувати поставлене завдання - звільнити Іловайськ [13].

Отже, перші бої за місто були невдалими для українських сил з низки причин: неналежне проведення розвідки щодо відомостей про противника; недостатня кількість одиниць бронетехніки, виділена для виконання завдання; низька якість техніки, якою забезпечили сили, задіяні у звільненні Іловайська; відсутність засобів зв’язку між підрозділами, що не давало можливості координувати свої дії та взаємодіяти між собою. Ці фактори вплинули на виконання поставленого завдання, що призвело до затягування звільнення міста.

\section{Список використаних джерел і літератури}

1. Бутусов Ю. Іловайськ. Фатальні рішення: [Електрон. ресурс]. Режим доступу : https://dt.ua/internal/ilovaysk-fatalni-rishennya-_.html.

2. Добробати / [Гладка К., Громаков Д., Миронова В., Шевченко А. та iн.]. - X., 2016. -570 c.

3. Донбас в огні. Путівник зоною конфлікту. - Львів, 2017. - 99 с.

4. Жирохов M. Хроники вторжения: когда реально русская армия вошла на Донбасс: [Електрон. ресурс]. - Режим доступу : 
https://fraza.ua/analytics/262740-hroniki-vtorzhenija-kogda-realno-russkajaarmija-voshla-na-donbass.

5. Зіненко Р. Війна, якої не було. Хроніка Іловайської трагедії. Ч. 1.7 24 серпня 2014 / [за ред. Ю. Х. Бутусова]. - 2019. - 446 с.

6. Книга пам'яті загиблих за Україну: Сокуренко Роман Олександрович: [Електрон. ресурс]. - Режим доступу: http://memorybook.org.ua/21/sokurenko.htm.

7. Марко С. Хроніка гібридної війни. - К., 2016. - 236 с.

8. Особистий архів авторів. Інтерв'ю 3 А. Поляковим (“Поляк”) стрільцем-санітаром 1-го взводу 1-ї штурмової роти батальйону “Донбас” (записано 31.07.2017).

9. Особистий архів авторів. Інтерв’ю з В. Дегтярьовим (“Сенсей”) командиром групи “Купол” (записано 31.07.2017).

10. Особистий архів авторів. Інтерв’ю з Д. Кулішом (“Сімьорка”) командиром окремого взводу снайперів батальйону “Донбас" (записано 01.08.2017).

11. Особистий архів авторів. Інтерв’ю 3 О. Дейнегою (“Чуб”) командиром відділення 1-го взводу 1-ї штурмової роти батальйону “Донбас" (записано 27.07.2017).

12. Особистий архів авторів. Інтерв'ю 3 О. Мотрієм - командиром батальйону “Кривбас” (записано 15.08.2017).

13. Особистий архів авторів. Інтерв’ю з О. Проскуряковим (“ВВС”) стрільцем 3-ї роти батальйону “Азов“ (записано 12.08.2017).

14. Особистий архів авторів. Інтерв’ю 3 С. Міщенком (“Яр”) стрільцем-санітаром 1-го взводу 1-ї штурмової роти батальйону “Донбас" (записано 27.07.2017).

15. Особистий архів авторів. Інтерв”ю з Т. Констанчуком (“Бішут”) командиром штурмової групи батальйону “Донбас” (записано 15.03.2017).

16. Особистий архів авторів. Інтерв’ю з Ю. Єременком (“Сімдесятий”) - офіцером бойового управління батальйону “Азов” (записано 02.08.2017). 
17. Особистий архів авторів. Інтерв’ю з Ю. Єременком (“Сімдесятий”) - офіцером бойового управління батальйону “Азов” (записано 29.03.2018).

18. Особистий архів авторів. Інтерв’ю 3 Ю. Сіньковським заступником командира батальйону “Кривбас" (записано 09.08.2017).

19. Особистий архів авторів. Інтерв’ю з Я. Тендітником (“Камиш”) заступником командира 1-го взводу 1-ї штурмової роти батальйону “Донбас” (записано 12.04.2018).

20.Особистий архів авторів. Інтерв'ю із А. Єременком - командиром відділення батальйону “Кривбас" (записано 10.08.2017).

21. Особистий архів авторів. Інтерв'ю із Р. Онищенком - заступником командира батальйону “Шахтарськ” (записано 21.03.2018).

22. Особистий архів авторів. Інтерв'ю із С. Бондаренком гранатометником батальйону “Кривбас” (записано 14.03.2017).

23. Особистий архів авторів. Інтерв'ю із С. Семенченком - командиром батальйону “Донбас” (записано 18.03.2017).

24. Павлюк А. Іловайська трагедія 2014 р.: події та відповідальність / Центр стратегічних справ УГСПЛ. - Х., 2016. - 48 с.

25. Перепелиия Г. Україна-Росія: війна в умовах співіснування. - К., 2017. $-880 \mathrm{c}$.

26. Применение артиллерии ВСУ в ходе войны на Донбассе: [Електрон. pecypc]. - Режим доступу : https://colonelcassad.livejournal.com/4693166.html/

27. Родин И. “Донбас”. Записки добровольца. 63 с. [рукопис наданий автором для авторів статті].

28. Російська військова техніка перетнула кордон України - іноземні журналісти: [Електрон. ресурс]. - Режим доступу : https://ua.korrespondent.net/ukraine/events/3406109-rosiiska-viiskova-tekhnikaperetnula-kordon-ukrainy-inozemni-zhurnalisty

29. Тинченко Я. Маринівка: стратегічна помилка 3 фатальними наслідками // Український тиждень. - 2014. - № 48. - С. 6-9. 
30. Тинченко Я. Серпень 2014-го. Іловайськ. Частина II. Чому добровольчі батальйони, а не Збройні Сили України, пішли на штурм міста: [Електрон. pecypc]. - Режим доступу : https://tyzhden.ua/Society/144115/

31. ЦДАВО України, ф. 1, оп. 46, спр. 04-54: Документи про розслідування обставин, що призвели до загибелі та захоплення в полон бійців добровольчих батальйонів, а також Збройних сил України. Т. 2. 241 арк.

32. ЦДАВО України, ф. 1, оп. 46, спр. 04-54: Документи про розслідування обставин, що призвели до загибелі та захоплення в полон бійців добровольчих батальйонів, а також Збройних сил України. Т. 3. 39 арк.

33. Цыганок A. Донбасс: неоконченная война. Гражданская война на Украине (2014-2016): русский взгляд. - М., 2016. - 680 с.

Benchuk V.O., graduate student of National University of Ostroh Academy (Ostroh);

Hrytsiuk V.M., Candidate of Historical Sciences, Associate Professor, Leading Researcher of Research Laboratory of Research Center of Military History of Ivan Cherniakhovskyi National Defense University of Ukraine (Kyiv)

\section{FIRST BATTLE FOR ILOVAYSK IN AUGUST 2014}

The results of military-historical research on the first battles in Ilovaysk between the defenders of Ukraine and the Russian occupation troops in August 2014 are offered to the attention of the scientific community. Due to the lack of archival documents and insufficient elaboration of the topic raised in historiography, the authors base their research on the recollections of event participants, using modern methodological approaches to oral history.

Keywords: aggression of the Russian Federation, armed conflict in eastern Ukraine, antiterrorist operation, Ilovaysk. 